\title{
Studi Historis Perkembangan Kaderisasi Ulama dalam Menghasilkan Fukaha
}

\author{
Rizal Darwis \\ IAIN Sultan Amai Gorontalo \\ Email: rizaldarwis@iaingorontalo.ac.id
}

\begin{abstract}
The existence of ulama as heirs of the Prophet occupies a strategic role in solving religious problems that occur in society. This research is a library research with the data source in the form of documentation. The data collected were analyzed using a qualitative descriptive method through a historical approach. The results showed that the existence of ulama needs to be maintained through a regeneration model. Historically, the ulama's regeneration model has been implemented since the era of the Prophet Muhammad, khulafa al-rasyidun, the formation of the school of thought to the era of the industrial revolution 4.0. The ulama's regeneration models are carried out using the question and answer model, the determination model, the story model, the da'wah model, and the demonstration model. The model for the regeneration of ulama in Indonesia is carried out with the model of education in Religious Higher Education, Islamic boarding schools and the education of ulama regeneration.
\end{abstract}

Keywords: Ulama, Regeneration, Fuqaha, Islamic Boarding Schools, Industrial Revolution 4.0

\section{Historical Study of the Development of Regeneration of Ulama in Creating Fuqaha}

\begin{abstract}
Abstrak: Keberadaan ulama sebagai pewaris Nabi menempati peran yang strategis dalam menyelesaikan persoalan keagamaan yang terjadi pada masyarakat. Penelitian ini adalah penelitian kepustakaan dengan sumber data berupa dokumentasi. Data yang dikumpulkan dianalisis dengan metode deskriptif kualitatif melalui pendekatan sejarah. Hasil penelitian menunjukkan bahwa keberadaan ulama perlu dijaga keberadaannya melalui model pengkaderan. Secara historis model pengkaderan ulama ini telah dilaksanakan sejak era Nabi Muhammad saw., khulafa al-rasyidun, masa pembentukan mazhab hingga era revolusi industri 4.0. Model-model pengkaderan ulama ini dilakukan dengan model tanya jawab, model penetapan, model kisah, model dakwah, dan model demonstrasi. Model pengkaderan ulama di Indonesia dilakukan dengan model pendidikan di Perguruan Tinggi Keagamaan, pesantren dan pendidikan kader ulama.
\end{abstract}

Kata Kunci: Ulama, Kaderisasi, Fukaha, Pesantren, Revolusi Industri 4.0 


\section{Studi Historis Perkembangan Kaderisasi Ulama dalam Menghasilkan Fukaha}

\section{A. Pendahuluan}

Fukaha atau ulama memiliki posisi yang sentral dalam masyarakat Islam dikarenakan digambarkan sebagai pewaris para Nabi. Ini berarti segala sifat, perilaku, kepribadian dan tindakannya menggambarkan apa yang dimiliki oleh para Nabi. Selain itu juga figur fukaha tidak hanya sebagai ilmuan yang menguasai agama, akan tetapi juga sebagai penggerak, motivator dan dinamisator dalam kehidupan bermasyarakat. Dawan Rahardjo menjelaskan ulama dalam Islam adalah pengemban tradisi keagamaan yang paham akan syariah. Terkadang disebut fakih dan biasanya ditunjuk menjadi hakim ( qadi) dan penasehat ahli dalam ilmu agama. Arti ulama secara luas adalah para ilmuwan yang ahli dalam kajian keagamaan, humaniora, ilmu sosial dan kealaman. Di kemudian hari dalam perkembangannya, pengertian ulama ini menjadi menyempit dan hanya digunakan untuk mereka yang ahli agama. ${ }^{1}$

Fukaha atau ulama mempunyai tugas dan tanggung jawab kepada masyarakat atau umat yang dibimbingnya. Seorang ulama dapat mengajarkan ilmu pengetahuan, memperbaiki iman dan akhlak masyarakat, serta memberikan solusi bagi permasalahan yang dihadapi masyarakat. Atas dasar inilah, maka pentingnya sebuah institusi pengkaderan fukaha atau ulama yang senantiasa siap dan tanggap terhadap perkembangan kemajuan ilmu pengetahuan dan perkembangan teknologi yang semakin modern dan canggih pada era revolusi industri ini.

Sebuah pendidikan dalam perkembangan zaman ini adalah sesuatu yang wajib dimiliki untuk mengarungi berbagai ancaman, hambatan dan tantangan di era modern ini. Globalisasi erat hubungannya dengan zaman modern ini. Hubungan internasional antara sebuah negara dengan negara yang lainnya semakin meningkat, dan menjadikannya saling terikat antara satu dengan yang lainnya, baik dari aspek sosial, hukum, budaya maupun pendidikan.

Secara eksternal dan internal tantangan dari pendidikan Islam pada era modern ini perbedaannya sangat jauh dengan tantangan yang dihadapi pada era sebelumnya, yaitu era klasik dan pertengahan. Pada era klasik dan pertengahan, tantangannya cukup

\footnotetext{
${ }^{1}$ Dawam Rahardjo, Ensiklopedi al-Qur'an “Ulama”, Ulumul Qur'an, No. 5, Volume VI, Tahun 1996.
} 
memberatkan, namun secara ideologis dan psikologis mudah dihadapi dan diatasi. Secara internal, sumber pengetahuan terhadap ajaran syariat Islam masih sangatlah dekat pada umat Islam ketika itu, semangat ijtihad masih sangat kuat untuk memajukan ajaran Islam. Secara eksternal, tantangan yang dihadapi adalah ancaman yang datangnya dari negara-negara yang sudah maju.

Islam dalam sejarah perkembangannya diketahui bahwa peran dan fungsi keulamaan pada zaman Rasulullah saw. langsung dipegang dan diambil alih Rasulullah saw. dibantu oleh para sahabat-sahabatnya. Persoalan-persoalan keagamaan dan sosial kemasyarakatan yang dihadapi oleh umat Islam ketika itu dapat langsung ditanyakan ke Rasulullah saw. untuk memperoleh solusi dan jawabannya.

Sepeninggal Rasulullah saw., fungsi dan peran keulamaan dilanjutkan oleh para sahabat-sahabat beliau, utamanya khulafa al-rasyidin dan amawiyin. Pada masa tersebut bermuncullah berbagai penafsiran terhadap nash-nash Alquran yang menjadi wahyu Rasulullah saw. Masalah-masalah yang tidak memiliki nash yang jelas, maka pintu ijtihad untuk menggali sebuah hukum (istinbath) terbuka luas. Posisi sahabat untuk menerangkan kedudukan hukumnya dan menghubungkannya antara satu dengan yang lainnya dan akhirnya menghasilkan sebuah fatwa. Di sinilah fungsi dan peran sahabat selaku selaku pembuat peraturan (musyarri). ${ }^{2}$ Setelah era khulafa al-rasyidin dan amawiyin, fungsi dan peran keulamaan selanjutnya dipegang oleh para ulama thabi'in dan thabi' thabi'in, sampai pada masa sekarang ini dipegang oleh ulama-ulama kontemporer.

Abad ke-17 dan ke-18, dinamika hukum Islam di dunia pada umumnya dan khususnya di Indonesia bersumber dari jaringan ulama-ulama yang terpusat dari Makkah dan Madinah. Memperbarui dan merevitalisasi ajaran-ajaran syariat Islam menjadi sebuah usaha sadar yang utama dilakukan oleh jaringan ulama tersebut. Ulama Indonesia khususnya, melakukan sebuah rekonstruksi sosio-moral pada masyarakat muslim. Ini membuktikan bahwa dalam jaringan ulama terdapat $43-44$.

${ }^{2}$ T. M. Hasb Ash-Shiddieqy, Pengantar Ilmu Fiqh (Cet. VIII; Jakarta: Bulan Bintang, 1993), h. 
hubungan ekstensif dan menimbulkan eskpresi dan semangat pembaruan di belahan dunia muslim. ${ }^{3}$

Pemahaman keilmuan dalam bidang hukum Islam akibat adaya hubungan kompleksitas para ulama yang terjadi dari jaringan ulama dari Makkah dan Madinah selanjutnya diimplementasikan sekembalinya ke negara-negara mereka masing-masing. Itu berarti bahwa produk hukum Islam kontemporer masa dewasa ini dan masa depan, pada dasarnya terwujud karena ada jaringan ulama yang kuat yang dipeoleh melalui jalur pendidikan.

Selanjutnya pada era revolusi industri 4.0 atau era disrupsi menimbulkan dampak yang tidak sederhana. Dampak yang ditimbulkan di era ini mencakup pada seluruh sendi-sendi dan aspek kehidupan manusia, termasuk dalam hal pendidikan. Peran teknologi cyber semakin sentral dalam kehidupan manusia. Mencermati adanya tanda perubahan ini, maka para ahli pendidikan menggunakan menggunakan istilah Pendidikan 4.0 (education 4.0), yaitu pendidikan yang telah mengintegrasikan antara teknologi cyber secara fisik dan non fisik ke dalam sistem pembelajaran. Pendidikan 4.0 adalah sebuah fenomena yang muncul untuk merespons kebutuhan akibat adanya revolusi industri 4.0. Manusia dan mesin diposisikan selaras untuk mendapatkan sebuah solusi, untuk memecahkan masalah dan bisa jadi dapat menemukan kemungkinan inovasi baru. ${ }^{4}$

Untuk menghadapi era dirupsi ini, di mana ulama bukan saja cakap dalam bidang agama, tetapi juga mencakup arti orang yang memahami berbagai ilmu pengetahuan, termasuk ilmu-ilmu umum dan menguasai ilmu pengetahuan dan teknologi (iptek). Selain itu pula, kaderisasi ulama (fukaha) sangat perlu dilaksanakan secara berkesinambungan dikarenakan ke depannya berbagai persoalan umat Islam menghadapi berbagai tantangan dengan berkembangannya iptek, sehingga dibutuhkanlah fatwa ulama untuk menyelesaikan persoalan hukum di tengah masyarakat Islam, dan saat ini, kaderisasi ulama yang telah dilaksanakan salah satunya adalah Pendidikan Kader Ulama (PKU).

\footnotetext{
${ }^{3}$ Azyumardi Azra, Jaringan Ulama: Timur Tengah dan Kepulauan Nusantara Abad XVII dan XVIII(Cet. II; Jakarta: Prenada Media, 2005), 8.

${ }^{4}$ Eduaksi, Pendidikan 4.0, Apa Itu?, dalam https://eduaksi.com/pendidikan-4-0-apa/, diakses tanggal 1 April 2020.
} 


\section{B. Pendidikan Kaderisasi Ulama Pada Masa Rasulullah saw., Khulafa al-Rasyidin, dan Masa Pembentukan Mazhab}

Pada zaman Rasulullah saw. fungsi dan peran keulamaan dipegang langsung oleh Rasulullah saw. dengan dibantu oleh sahabat-sahabat yang memiliki kompetensi keilmuan dan wawasan yang luas. Oleh karena dalam kehidupan masyarakat akan bermunculan berbagai persoalan, baik itu menyangkut permasalahan keagamaan, maupun sosial kemasyarakatan. Di zaman ini, segala persoalan yang ditanyakan dapat langsung dapat ditanyakan langsung kepada Rasulullah saw. untuk mendapatkan jawaban.

Posisi Rasulullah pada saat itu memiliki peran ganda, yaitu satu sisi berperan sebagai ulama, dan di sisi lain berperan sebagai umara. Peran ganda ini membentuk sebuah integritas ri'asah al-din wa al-daulah, yakni seorang pemimpin agama sekaligus pemimpin negara. Sepeninggal Rasulullah saw. peran tersebut dilanjutkan oleh para sahabat beliau, dan gelar yang diberikan adalah khalifah (pengganti). Khalifah tersebut secara berturut-turut adalah Abu Bakar ash-Shiddiq, Umar bin Khattab, Utsman bin Affan dan Ali bin Abi Thalib.

Bahaking Rama menjelaskan dalam proses penciptaan kaderisasi di masa Rasulullah saw. dan khulafa al-rasyidin menggunakan beberapa metode, antara lain: ${ }^{5}$

\section{a. Metode Tanya Jawab}

Rasululah saw. dalam mengajarkan ajaran Islam, salah satu metode yang digunakannya adalah metode tanya jawab, dan berdialog dengan para sahabat secara langsung. Dalam hal ini, biasanya sahabat bertanya kepada Rasululah saw., lalu Rasululah saw. menjawab, akan tetapi terkadang pula Rasululah saw. melemparkan pertanyaan kepada para sahabat tersebut untuk menarik perhatian para sahabat.

${ }^{5}$ H. Bahaking Rama, Sejarah Pendidikan Islam (Cet. I; Jakarta: PT. Pradotama Wiranegara Gemilang, 2002), 52-54. 
Studi Historis Perkembangan Kaderisasi Ulama dalam

Menghasilkan Fukaha

\section{b. Metode Taqririyah (Penetapan)}

Metode ini terlihat saat Rasululah saw. membenarkan dengan cara mendiamkan perbuatan yang sudah dikerjakan oleh sahabat yang sebelumnya tidak ada petunjuk dari Rasulullah saw. Setelah perbuatan tersebut dilakukan oleh sahabat dan diketahui oleh Rasulullah saw., lalu mendiamkan atau tidak melarang perbuatan yang telah dikerjakan oleh sahabat tersebut. Misalnya sikap Rasulullah saw. membiarkan para sahabat dalam memberikan penafsiran terhadap sabdanya tentang salat pada suatu peperaangan, yaitu: lā yușalliyyinna ahadun al-aṣra illā fí banī qurayḍah (janganlah seorang pun salat asar kecuali nanti di Bani Quraidhah).

\section{c. Metode Kissah (Kisah)}

Metode kissah ini ialah sebuah metode dengan cara menceritakan atau mengkisahkan suatu keadaan umat manusia pada zaman dahulu untuk dijadikan i'tibar kepada umat sekarang. Kissah-kissah tersebut misalnya bagaimana kehancuran kaum Tsamud akibat dari perbuatan durhaka mereka terhadap Allah swt., kissah Abu Lahab dan istrinya yang binasa akibat ingkar kepada rasul Allah swt., dan berbagai kissah lainnya yang ada dalam Alquran.

\section{d. Metode Khutbah (Dakwah)}

Metode khutbah ini adalah salah satu metode yang seringkali digunakan Rasululah saw. dalam menyampaikan ajaran atau pembelajaran kepada umat Islam. Misalnya sewaktu Rasululah saw. menyampaikan ajaran Islam pertama kalinya kepada beberapa orang muslim di Mekkah. Berdasarkan hal itulah, maka metode ini selanjutnya menjadi tuntunan dalam pelaksanaan ibadah shalat Jum'at.

\section{e. Metode Fi'liyah (Demonstrasi)}

Metode fi'liyah telah digunakan oleh Rasulullah saw. sendiri dalam mengajarkan shalat kepada sahabatnya. Caranya dengan mendemonstrasikan gerakan shalat di depan mata mereka. Hal ini dilakukan agar pelaksanaan shalat lebih jelas diketahui dan mudah ditiru. Pemberian demonstrasi ini diabadikan dalam 
sebuah hadis Rasulullah saw.: "shallu kama raitumuniy ushalliy"6 (shalatlah sebagaimana kamu melihat saya shalat).

Kesimpulannya bahwa pada era klasik, yang dimulai pada era Rasulullah saw. dan era khulafa' al-rasyidun diketahui bahwa ada beberapa metode yang digunakan dalam pengkaderan ulama sebagai metode-metode tersebut di atas. Metode-metode tersebut nampak efisien dan efektif dalam kegiatan pelaksanaan kaderisasi.

Dekade selanjutnya selapas pemerintahan khulafa al-rasyidin berakhir dilanjutkan oleh Mu'awiyah. Pada masanya lahir fenomena baru, karena sebagaimana diketahui Mu'awiyah bukanlah tipe seorang pemimpin agama, tetapi beliau adalah seorang pemimpin politik yang mumpuni dan piawai. Berdasarkan hal tersebut maka pada masanya kepemimpinan dipisahkan dari kepemimpinan di bidang agama (ulama) dan kepemimpinan di bidang politik (umara').

Ketika kepemimpinan tidak lagi berada di satu tangan, maka ulama dan umara' menempati dua posisi yang berbeda. Umara' yang bijak selalu menempatkan ulama sebagai penasehat mereka. Ulama dalam pandangan umara', adalah orang yang lebih tahu tentang hukum Islam, baik yang berkaitan dengan masalah keagamaan maupun urusan duniawi.

Meski tidak dipungkiri sepeninggal Rasululah saw. muncullah beberapa mazhab di kalangan sahabat Nabi saw., seperti mazhab Umar, Aisyah, Ibn Umar, Ibn Abbas, Ali dan lain sebagainya. Kemudian sahabat dikelompokkan dalam dua golongan besar, yaitu: 1) Kelompok Ahl al-Bait dan dan para pengikutnya, seperti: Ali dan kedua putranya, Abu Dzar, Miqdad, Ammar ibn Yazir, Hudzaifah, Abu Rafi' Maula Rasulullah, Ummi Salamah dan sebagainya; 2) Kelompok di luar $A h l$ al-Bait, seperti: Abu Bakar, Aisyah, Umar, Ustman, Abu Hurairah. ${ }^{7}$

Murtadha al-Askariy sebagaimana dikutip Jalaluddin Rahmat menyebut dua mazhab awal tersebut ini sebagai Madrasah al-Khulafa' dan Madrasah Ahl al-Bait.

\footnotetext{
${ }^{6}$ Abi Abdillah Muhammad bin Ismail bin Ibrahim bin al-Mugirah bin Bardzbah al-Bukhariy alJa'afiy, Shahih al-Bukhariy, al-Kitab al-Adzan, al-Bab al-Adzan Lilmusafir idza Kanu Jama'atan, No. Hadis: 595, dalam Mausu'ah al-Hadits al-Syarif ver. 2 [CD ROM]. Jami` al-Huquq Mahfudzah li Syirkah al-Baramij al-Islamiyah al-Dauliyah, 1991-1997.

${ }^{7}$ Jalaluddin Rahmat, Dahulukan Akhlak di Atas Fiqih (Cet. I; Jakarta: Mizan, . 2007), 180.
} 
Kedua madrasah ini berbeda dalam melakukan penafsiran Alquran, memandang Sunnah Rasulullah dan melakukan istimbat hukum. Pada saat zaman kekuasaan dari Dinasti Umayyah, Madrasah al-Khulafa' bercabang lagi ke dalam dua cabang besar, yaitu 1) Madrasah al-Hadits berpusat di Madinah dengan melandaskan fikihnya pada Alquran, Sunnah, ijtihad para sahabat dan menghindari sedapat mungkin penggunaan ra'yu dalam penetapan hukum; dan 2) Madrasah al-Ra'yu yang berpusat di Irak dengan sedikit penggunaan hadis dan kebanyakan berpijak pada penalaran rasional dan melihat illat (sebab hukum) dan maqasid syari'iyyah (tujuan syara). Madrasah Ahl al-Bait tumbuh dan berkembang "di bawah tanah" mengikuti para imam mereka, karena tekanan dan penindasan. Mereka melakukan pengembangan esoterisme dan disimulasi untuk memelihara corak fikih mereka. Jadi dalam upaya kaderisasi, baik Madrasah al-Khulafa' dan Madrasah Ahl al-Bait, menempatkan pemimpin mereka sebagai panutan sesuai dengan sumber pokok pengambilan hukum yang dipergunakan pemimpin mereka. ${ }^{8}$

Pada zaman kekuasaan Bani Abbasiyah timbullah beberapa mazhab, seperti mazhab Hanafi, mazhab Maliki, mazhab Syafi'i dan mazhab Hanbali. Keempat imam tersebut dalam mengkader para pengikutnya untuk pengambilan keputusan hukum (fiqh) bertitik tolak pada beberapa sumber hukum, seperti: Alquran dan alsunnah, ijma, dan pendapat para sahabat; qiyas, istihsan, mashalih mursalah, sadd alzara'i, istishab, syar'u man qablana, dan sebagainya.

Keempat imam mazhab di atas dalam pengambilan keputusan hukum antara satu sama lain hampir sama, namun perbedaannya hanya dalam skala priorititas sumber hukum mana yang didahulukan sesuai kondisi pada saat itu. Begitu pula pada saat pengkaderan murid-muridnya, sumber-sumber hukum tersebut yang diperkenalkan kepada murid-muridnya.

\section{Pendidikan Kaderisasi Ulama di Era Revolusi Industri 4.0}

Kaderisasi ulama bagi banyak pihak adalah program yang sangat penting dalam memajukan Islam, sehingga perlu adanya perhatian bagi berbagai kalangan. Ini dapat

\footnotetext{
${ }^{8}$ Ibid., 180-181.
} 
dilihat dari ungkapan Hidayat dalam Saridjo bahwa ketika jumlah kiyai dan pesantren yang memiliki wibawa, moral dan keilmuan yang semakin menurun maka perlu adanya agenda serius bagi umat. Jika pemimpin formal dan informan tidak memiliki wibawa lagi, maka kemana masyarakat akan mengadu, sehingga atas dasarnya inilah lembaga pesantren dan kiyai memiliki peran strategis dalam mengisi kekosongan pemimpin yang menjadi panuran dan kiblat masyarakat. ${ }^{9}$

Pendidikan Islam pada era revolusi industri 4.0 menghadapi tantangan dengan pertarungan ideologi-ideologi besar di dunia seperti halnya negara-negara maju, semisal Amerika, Jepang, China, Benua Eropa, dan negara-negara lainnya. Menurut Daniel Bell sebagaimana dikutip oleh Abuddin Nata, ada lima tanda kecenderungan di era globalisasi dunia, antara lain:

1. Kecenderungan terhadap integrasi ekonomi yang mengakibatkan terjadinya persaingan bebas dalam berbagai bidang, terutama pada bidang pendidikan. Hal ini termasuk pendidikan Islam akan terpengaruh dengan doktrin-doktrin Barat yang hanya mengandalkan logika saja.

2. Kecenderungan terhadap fragmantasi politik yang mengakibatkan terjadinya peningkatan tuntutan dan harapan dari masyarakat. Masyarakat tentunya akan menuntut bagaimana kesejahteraan hidupnya.

3. Kecenderungan terhadap penggunaan high technology (teknologi tinggi), seperti teknologi informasi dan komunikasi (TIK). Kehadiran TIK ini mengakibatkan terjadinya tunt utan dari masyarakat untuk memperoleh pelayanan yang lebih cepat dan transparan serta tidak dibatasi oleh waktu, ruang, dan tempat.

4. Kecenderungan terhadap saling tergantungan (interpendensi), yaitu suatu keadaan seseorang yang dapat memenuhi kebutuhannya jika dibantu orang lain. Berbagai stategi dan siasat yang dilakukan oleh negara-negara maju untuk menjadikan negara-negara berkembang tergantung kepadanya, sehingga hal demikian terjadi dengan cara yang intensif.

5. Kecenderungan yang munculnya akibat adanya penjajahan baru pada bidang kebudayaan (new colonization in culture) yang menyebabkan terjadinya mindset

${ }^{9}$ Marwan Saridjo, Mereka Bicara Pendidikan Islam: Sebuah Bunga Rampai (Jakarta: DPP GUPPI, 2009), 7. 


\section{Studi Historis Perkembangan Kaderisasi Ulama dalam Menghasilkan Fukaha}

(pola pikir) masyarakat pengguna pendidikan, yaitu mereka dari yang semula belajar dalam rangka peningkatan kemampuan moral, intelektual, fisik dan psikisnya, mengalami perubahan menjadi belajar untuk memperoleh pekerjaan dan penghasilan yang besar. ${ }^{10}$

Dampak dari adanya kecenderungan tersebut bagi pendidikan kaderisasi ulama di era disrupsi adalah bagaimana mempersiapkan calon ulama bukan hanya mengetahui dan memahami kajian-kajian keislaman semata, akan tetapi juga melek terhadap penggunaan teknologi.

Pendidikan Islam dalam perkembangan sejarahnya tidak terlepas dari jaringan ulama nusantara melalui sebuah perjalanan ibadah haji yang berkisar pada abad ke-17 di mana perjalanan ulama nusantara ke Haramain. Hal ini diungkapkan oleh Voll bahwa ada tiga tipe, yaitu:

1. Little immigrants, yaitu orang-orang yang datang dan bermukim di Mekkah yang dalam hal beragamanya telah menyerap perilaku masyarakat setempat.

2. Grand immigrants, yaitu orang-orang yang datang dan bermukim di Mekkah yang memiliki dasar agama yang baik.

3. Para ulama dan murid pengembara, yaitu orang-orang yang menetap di Mekkah dan Madinah dalam pengembaraanya menuntut ilmu, dan setelah memiliki ilmu yang memadai dan otoritas untuk mengajar, maka mereka kembali ke negeri asalnya. $^{11}$

Di sini nampak bahwa posisi ulama dalam Islam adalah sebagai pengemban tradisi agama dan memiliki kemampuan dalam memahami syariah. Djohan Effendi menyebutkan bahwa perkembangan ulama di Indonesia, istilah ulama menyempit hanya kepada ahli agama. Hal ini dapat diketahui dari istilah-istilah yang tersebar di Nusantara, misalnya sebutan Kiyai di Jawa; Ajengan di Sunda; Tuan Guru di Nusa

${ }^{10}$ Daniel Bell, The Coming of Post Industrial Society dalam Abuddin Nata, Kapita Selekta Pendidikan Islam: Isu-Isu Kontemporer tentang Pendidikan Islam, Ed. 1 (Cet. 2; Jakarta: RajaGrafindo Persada, 2013), 14-16.

${ }^{11}$ J. O Voll, "Scholarly Interrelations between South Asia and Middle East in the $18^{\text {th }}$ Century," Proccedings of The South Asia Seminar, University of Pennyslvania), Vol. 3, 1988, 51. 
Tenggara, Kalimantan Selatan, dan Kalimantan Tengah; Tengku di Aceh, Syekh di Sumatera Utara (Tapanuli); Buya di Minangkabau. ${ }^{12}$

Pengkaderan ulama di Indonesia dapat dilihat dari beberapa model pendidikan, misalnya:

1. Perguruan Tinggi Keagamaan Islam (PTKI)

PTKI sebagai sebuah lembaga pendidikan tinggi dewasa ini mempersiapkan dirinya pada berbagai tantangan besar di era dirupsi. Era dirupsi tidak hanya mendorong terjadinya transformasi peradaban melalui proses modernasi, industrialisasi, dan reformasi teknologi. Transformasi itu mengalami perubahan yang serba cepat di berbagai bidang kehidupan, baik sosial, budaya, ekonomi, politik, maupun pendidikan.

Perguruan Tinggi di bawah naungan PTKI terdiri atas Universitas Islam Negeri (UIN) sebanyak 17 lembaga, Institut Agama Islam Negeri (IAIN) sebanyak 34 lembaga, dan Sekolah Tinggi Agama Islam Negeri (STAIN) sebanyak 7 lembaga. ${ }^{13}$ Perguruan-perguruan tersebut diharapkan dapat mencetak intelektual kyai atau kyai intelektual, di mana islamic studies merupakan wilayah kajiannya. PTKI diharapkan mengambil peran sebagai pencetak ulama dan ilmuwan. Harapan ini dapat bersifat sosial (social expectations) dan bersifat akademik (academic expectations). ${ }^{14}$

PTKI dewasa ini membuka berbagai profesi yang dibutuhkan masyarakat, di mana bagi mahasiswanya yang berminat menjadi ulama dapat mengambil berbahai program studi khusus, seperti program studi Alquran, program studi hadis, program studi syariah (fikih) dan lain sebagainya. Juga mahasiswa yang ingin menjadi ilmuwan (saintis) dapat mengambil program-program studi umum, seperti ekonomi, psikologi, sains, teknik, kedokteran dan lain sebagainya.

PTKI sebagai pencetak kader ulama berupaya membekali mahasiswanya untuk mumpuni dalam kajian keislaman yang disinergikan dengan kajian ilmu umumnya

\footnotetext{
${ }^{12}$ Djohan Effendi dalam Dawam Rahardjo, Ensiklopedi al-Qur'an “Ulama”, Ulumul Qur'an, No. 5, Volume VI, Tahun 1996.

${ }^{13} \mathrm{https} / / /$ id.wikipedia.org/wiki/Daftar_perguruan_tinggi_Islam_negeri_di_Indonesia, diakses tanggal 2 Mei 2019.

${ }^{14}$ Direktorat Pendidikan Tinggi Islam, Petunjuk Teknis Bantuan Program Peningkatan Mutu Penelitian Tahun 2015 (Jakarta: Kementerian Agama RI, 2015), 3.
} 


\section{Studi Historis Perkembangan Kaderisasi Ulama dalam Menghasilkan Fukaha}

lainnya. Harapan PTKI untuk mencetak intelektual kyai atau kyai intelektual dapat terwujud adanya.

\section{Pesantren}

Kaderisasi ulama di Indonesia dilakukan melalui sebuah proses pendidikan di pesantren. Hal ini disebabkan pesantren didirikan bertujuan untuk mencetak para ulama. Dhofier mengemukakan bahwa pesantren adalah sebuah tempat khusus untuk mendidik dan mengajarakan santri atau peserta didik yang ingin mendalami dan memahami pengetahuan agama Islam dengan menggunakan cara-cara tertentu yang khas. ${ }^{15}$ Olehnya itu diketahui bahwa tujuan pendidikan pada pondok pesantren adalah untuk mendidik dan mengajarkan para santri untuk memiliki pengetahuan tentang agama Islam yang benar dan mendalam.

Pondok pesantren dapat disebut sebagai salah satu model pendidikan Islam yang khas Indonesia. Jumlah pesantren tersebut di Indonesia sebanyak 25.938 pesantren. ${ }^{16}$ Pesantren dengan berbagai variannya dalam sejarah Indonesia dapat ditelusuri keberadaannya sampai abad ke-13 M sebagai lembaga pendidik yang berkembang sangat subur di wilayah pedesaan dan wilayaj daerah terpencil. ${ }^{17}$ Pertumbuhan dan perkembangan pondok pesantren kemudian menunjukkan sebagai suatu bagian dari pengembangan dakwah Islam di Pulau Jawa oleh para wali-wali, dimana para wali-wali tersebut lebih dikenal sebagai Walisongo. Keberadaan Walisongo di pondok pesantren memegang peranan yang semakin kuat dengan adanya keberpihakan dari para penguasa kerajaan Islam ketika itu, seperti Sultan Agung di Kerajaan Mataram Islam. ${ }^{18}$

Sejarah perkembangan pesantren menunjukkan tempat untuk pembinaan caloncalon ulama (reproduction of ulama). ${ }^{19}$ Model pembelajannya tidak terlepas dari

\footnotetext{
${ }^{15}$ Zamakhsyari Dhofier, Tradisi Pesantren: Studi tentang Pandangan Hidup Kyai (Jakarta: LP3ES, 1982), 45.

${ }^{16} \mathrm{http}: / /$ pbsb.ditpdpontren.kemenag.go.id/pdpp/ diakses tanggal 2 April 2020.

${ }^{17}$ Murdan, "Pondok Pesantren dalam Lintasan Sejarah" dalam Ittihad Jurnal Ilmi: Keagamaan, Pendidikan dan Kemasyarakatan, Vol. 2 No.1 April 2004 (Banjarmasin: Kopertais Wilayah XI Kalimantan, 2004), 33-45.

${ }^{18}$ Ibid., 33-45.

${ }^{19}$ Azyumardi Azra, Esei-Esei Intelektual Muslim dan Pendidikan Islam (Jakarta: Logos Wacana Ilmu, 1998), 89.
} 
pembacaan kitab kuning. Kurikulum pesantren menempatkan Kitab Kuning sebagai sebuah posisi istimewa, sehingga inilah menjadi ciri pembeda dari lembaga-lembaga yang bercorak pendidikan Islam lainnya. Pada beberapa pesantren sistem pengajaran kitab kuning memiliki kesamaan dalam bentuk sorogon dan bandongan. Hal ini dapat ditemukan pada pesantren-pesantren di Jawa dan Madura. ${ }^{20}$

Penyebaran kitab kuning sebagai literatur keagamaan klasik dilakukan oleh ulama melalui bentuk pengajian di rumah atau lembaga-lembaga keagamaan seperti pesantren, manasah, suraui, rangkang dan lainnya. Di tempat tersebutlah kitab-kitab klasik dipelajari dan dikembangkan untuk mencerdaskan masyarakat dan menyebarkan ajaran Islam di Nusantara. Olehnya itu tidak anehlah jika literatur klasik atau kitab kuning memiliki hubungan yang tidak terpisahkan dengan pesantren, malahan masyarakat menganggap bahwa pesantren itu identik dengan kitab-kitab kuning.

Walaupun dalam sejarah sulit melacak waktu mulai terjadinya penyebaran literatur keagamaan Islam (kitab klasik) di Indonesia. Beberapa temuan terkait literatur keagamaan melalui catatan-catatan lokal dan asing, misalnya Hikayat Raja-Raja Pasai, sejarah Melayu dan kitab perundang-undangan pada beberapa kesultanan Indonesia yang membahas persoalan syariah atau fikhiyah yang diambil dari mazhab Imam Syafi'i walaupun tidak mencatumkan rujukannya. ${ }^{21}$ Literatur keagamaan tersebut diajarkan oleh para ulama melalui pengajian melalui rumah-rumah dan kemudian berkembang dengan terbentuknya lembaga pesantren.

Pesantren sebagai salah satu lembaga pendidikan Islam yang mengalami perubahan dan perkembangan sesuai dengan adanya perubahan zaman, dipengaruhi terutama oleh adanya perkembangan dan dampak adanya ilmu pengetahuan dan teknologi. Perubahan bentuk pesantren ini tidak menghilangkan ciri khasnya sebagai sebuah institusi pesantren. Dhofier menjelaskan bahwa tipe-tipe pesantren ada dua, yaitu pesantren tradisional (salaf) dan pesantren modern. ${ }^{22}$ Sedangkan Haidar

\footnotetext{
${ }^{20}$ Dhofier, Tradisi Pesantren, 51.

${ }^{21}$ Azumardi Azra, Pendidikan Islam: Tradisi Modernisasi Menuju Milenium Baru (Jakarta: Logos Wacana Ilmu, 2002); 112.

${ }^{22}$ Ibid., 44-45.
} 
membaginya dalam tiga tipe, yaitu pesantren tradisional, pesantren modern, dan pesantren komprehensif. $^{23}$

Pesantren dalam pengertian ini tetap merupakan sebuah lembaga pendidikan Islam yang tumbuh dan berkembang dari masyarakat dan untuk masyarakat. Olehnya itu pesantren memiliki tipe antara lain:

\section{a. Pesantren Tradisional}

Pesantren tradisional ini masih tetap mempertahankan bentuk keasliannya yang semata-mata mengajarkan kitab-kitab yang ditulis oleh para ulama abad ke 15 dengan menggunakan dan bertuliskan bahasa Arab. Pola pembelajarannya dengan menggunakan sistem halaqah yang dilaksanakan di masjid atau surau.

Tujuan dari sistem pendidikan dan pengajaran halaqah adalah penghafalan dengan titik akhir dari segi metodologinya cenderung kepada terbentuknya santri yang menerima dan memiliki ilmu. Dalam artian bahwa ilmu tidak berkembang ke arah paripurnanya ilmu itu kecuali hanya terbatas pada apa yang telah diberikan oleh kiayinya. Kurikulumnya sepenuhnya disusun oleh kiyai sebagai pengasuh pondoknya. Santri pada model pesantren tradisional in ada yang menetap di dalam pondokan dan ada santri yang tidak menetap di dalam pondokan.

\section{b. Pesantren Modern}

Pesantren modern merupakan pengembangan tipe pesantren. Hal ini dikarenakan orientasi belajar jenis pesantern ini cenderung mengadopsi seluruh sistem belajar secara klasik dan sistem belajar tradisional juga ditinggalkan. Penerapan sistem belajar modern pada pesantren modern ini terutama terlihat dari penggunaan ruanganruangan belajar, baik dalam bentuk madrasah ataupun sekolah. Kurikulum yang digunakan ialah kurikulum sekolah yang berlaku secara nasional. Santri pada pesantren modern ada yang menetap dan yang mendiami lingkungan di sekitar pesantren. Kedudukan para kiyai pada pesantren modern sebagai koordinator pelaksana dalam proses pembelajaran yang dilaksanakan di dalam ruangan kelas. Perbedaannya sekolah dengan madrasah terdapat pada porsi pendidikan agama dan bahasa Arab yang lebih

${ }^{23}$ Haidar Putra Daulay, Dinamika Pendidikan Islam di Asia Tenggara (Cet. I; Jakarta: PT Rineka Cipta, 2009), 20. 
ditonjolkan dan dijadikan sebagai kurikulum lokal. Tentunya ini menjadi penciri khas dari kedua lembaga tersebut.

c. Pesantren Komprehensif

Pesantren komprehensif merupakan sebuah sistem pendidikan dan pengajaran yang memadukan antara model pembelajaran tradsional dan modern. Maksudnya adalah diterapkan dan diimplementasikan pendidikan dan pengajaran kitab kuning dengan metode sorongan, bandongan dan wetonan, namun secara regular sistem persekolahan pun terus dikembangkan. Bahkan pendidikan dan keterampilan juga ditumbuhkembangkan sehingga membuat pesantren tipe ini berbeda dengan model pesantren lainnya. Selain itu juga pendidikan masyarakat dimasukkan pula dalam program yang digarap oleh pesantren tersebut. Intinya yaitu pesantren komprehensif merupakan lembaga pendidikan yang bertujuan ikut berperan aktif aktif dalam pembangunan sosial kemasyarakatan.

\section{Pendidikan Kader Ulama (PKU)}

PKU telah diselenggarakan oleh MUI Tingkat Pusat sejak tahun 1985 dengan waktu penyelenggaraan selama 15 hari, 3 bulan, atau 24 bulan. Dalam perkembangannya selama 27 tahun, eksistensi alumninya belum menunjukkan keberhasilan, sehingga mendorong MUI untuk menyelenggarakan PKU jenjang S1 (sarjana) dengan harapan mmemiliki kemampuan akademis dalam ilmu-ilmu keislaman (ulum al-islamiyah) dan khazanah literatur Islam (turats Islam). ${ }^{24}$

PKU sifatnya non formal. Sebagai pendidikan non formal peserta PKU diikuti oleh banyak kegenerasi muda yang tentunya diharapkan menjadi pemimpin masa depan. Peserta pendidikan mendapatkan materi-materi keagamaan seperti tafsir, hadis, fikih dengan merujuk pada sumber klasik (kitab kuning). ${ }^{25}$ Materimateri seperti yang disebutkan ini kelihatannya memang efektif dan dalam upaya menciptakan ulama masa depan, pengkaderan tersebut masih harus diisi dengan

\footnotetext{
${ }^{24}$ Abdulloh, "Sistem Perencanaan Pendidikan Kader Ulama (PKU) Sarjana Strata Satu (S1) pada Komisi Pendidikan Majelis Ulama Indonesia (MUI) Pusat," Skripsi (Jakarta: UIN Syarif Hidayatullah, 2012), ix.

${ }^{25}$ MUI Sulawesi Selatan. Brosur Pendidikan Kader Ulama. Makassar, 2000, 2.
} 
materi-materi yang benar-benar dibutuhkan dalam melaksanakan tugasnya sebagai ulama seperti pengetahuan tentang permasalahan sosial, metode pemecahan masalah, metode/pendekatan sosial, retorika, dan lain sebagainya. Dengan cara demikian, peserta pendidikan akan memiliki bekal yang cukup menghadapi tantangan masa depan yang global.

Selain itu, dilihat dari segi peran dan fungsinya, PKU harus mampu menyadarkan pada calon ulama tentang peran dan fungsinya yang amat strategis dan penting dalam rangka pembinaan umat. Dengan menyadari fungsinya ini, peserta pendidikan akan melaksanakan tugasnya sebagai panggilan moral, dan bukan karena mengharapkan keuntungan sesaat.

Ulama seharusnya memiliki kualifikasi ilmu dan kualifikasi akhlak, juga memahami bahwa betul misi kenabian karena mereka adalah pewaris para nabi, memahami dan menguasai ilmu-ilmu agama, baik itu segi paham pemikiran Islam, paham pemikiran kontemporer, paham terhadap strategi perjuangan dalam mengembang misi kenabian, sehingga di sinilah ulama bukan hanya menguasai ilmu keislaman, tetapi juga bisa mengaplikasikannya dengan penuh hikmah. Juga ulama hendaknya memiliki kualifikasi akhlak, yaitu sebuah sikap yang hanya takut kepada Allah swt, tidak mencintai kehidupan dunia, apalagi gila terhadap jabatan dan kekuasaan. Olehnya itu di sinilah akan pentingnya melakukan sebuah pengkaderan ulama.

Pendidikan kader ulama ini di Indonesia salah satunya dilakukan oleh organisasi besar Muhammadiyah. Hasil penelitian dari Isnanto menyebutkan bahwa pada organisasi Muhammadiyah mengalami krisis ulama, bahkan terjadi krisis dai, yaitu krisis ulama yang intelektual dan intelektual ulama. Adanya krisis ulama ini dikarena dua faktor, yaitu faktor internal kelembagaan yang tidak berfungsi dengan baik dari segi stukturnya, dan juga faktor eksternal di mana pola pikir yang terbentuk dari peninggalan kolonial, adanya tarik menarik kepentingan politik di organisasi Muhammadiyah serta standar ulama di Muhammadiyah, sehingga atas dasar itulah secara kelembagaan perlu adanya sebuah kesadaran yang kolektif akan 
pentingnya pengkaderan ulama dan secara sosial perlu adanya kesadaran warga Muhammadiyah akan pentingnya pendidikan kader ulama. ${ }^{26}$

Ulama yang ideal dalam konsep Muhammadiyah perlu menguasai ilmu-ilmu kesyariahan, takut kepada Allah swt., berperan aktif dalam membimbing dan memperjuangkan kepentingan umat, aktif dalam organisasinya, mampu membaca kitab kuning dan kitab putih (buku-buku yang terkait dengan ilmu alam). Artinya bahwa ulama tidak hanya paham dan menguasi ilmu ushul fikih, fikih, tafsir dan hadis, namun juga menguasai ilmu politik, manajemen, sosiologi dan lain sebagainya. $^{27}$

Soleh Iskandar dalam Assiroji mengemukakan ada lima syarat seorang ulama antara lain:

1. Memiliki penguasaan ilmu agama (mutafaqquh fi al-din) dan mampu mencetak insan yang tafaqquh fi al-din.

2. Memiliki penghayatan dan pengamalan ajaran Islam dengan ikhlas yang semata-mata sebagai bentuk pengabdian kepada Allah swt.

3. Memiliki kemampuan menghidupkan sunnah Rasulullah dan menyebarkan ajaran agama Islam secara kaffah.

4. Memiliki akhlak yang tinggi, berpikir kritis, berjiwa dinamis, kreatif dan istikamah.

5. Memiliki jiwa besar, bermental dan berfisik kuat, hidup sederhana, tahan terhadap ujian, rendah hati, kasih saying terhadap sesame, berjamaah, cinta dan tawakkal kepada Allah swt. ${ }^{28}$

Kriteria ulama di atas tentunya memberikan pemahaman bahwa seorang ulama adalah seseorang yang memiliki penguasaan dari segi agama dan melek terhadap perkembangan teknologi yang kemudian dapat diaplikasikan dalam kehidupan masyarakat sebagai seseorang yang menjadi panutan bagi umat.

\footnotetext{
${ }^{26}$ Muh. Isnanto, "Gagasan dan Pemikiran Muhammadiyah tentang Kaderisasi Ulama (Studi Kasus tentang Ulama di Muhammadiyah)," Aplikasia: Jurnal Aplikasi Ilmu-ilmu Agama, Vol. 17, No. 2, 2017; 95.

${ }^{27}$ Ibid., 101.

${ }^{28}$ Dwi Budiman Assiroji, "Konsep Kaderisasi Ulama di Indonesia," Edukasi Islami: Jurnal Pendidikan Islam, Vol. 09/No 01 Februari 2020; 54.
} 


\section{Peran Ulama dalam Pembentukan Hukum di Era Revolusi Industri 4.0}

Hukum dapat dipahami sebagai ketentuan-ketentuan yang bersumber dari nash Alquran dan sunnah Rasulullah saw. Manusia dalam menjalani kehidupannya tidak terlepas dari aturan hukum, sehingga olehnya itu perlu diatur aturan berupa norma-norma hukum yang diambil dari ajaran-ajaran Islam. Manusia selain menjalani kehidupan di dunia, juga akan mengalami kehidupan di akhirat yang kebahagiaan dan kesengsaraannya ditentukan oleh akumulasi pahala dari perbuatanperbuatannya di dunia.

Warisan Islam yang Rasulullah saw. telah berikan kepada umat manusia untuk bisa dipelajari dan dikembangkan serta dijadikan acuan bagi umatnya ada dua, yaitu ajaran yang tertuang dalam Alquran dan hadis. Kajian terhadap ajaranajaran Alquran dan hadis erat hubungannya dengan al-ra'yu yang kemudian akan melahirkan serangkaian pemikiran teoritis. Dikatakan demikian, karena dengan alra'yu akan memperkaya informasi faktual tentang dinamika hukum-hukum Islam.

Kaitannya dengan pembuatan hukum, Muin Salim menyatakan bahwa "fikih Islam menganut pandangan bahawa hukum tidak bersumber dari Allah dan RasulNya, tetapi juga dari para pendapat ulama, baik secara konsensus ataupun secara individual. Hal ini berbeda dengan apa yang dikenal dalam sistem hukum nasional yang mengenal lembaga pembuat undang-undang dan peraturan lainnya yang berlaku sebagai hukum positif, dan karena hukum dimaksudkan untuk berlaku umum dalam suatu masyarakat, maka kiranya amatlah sulit diterima bagaimana pendapat perorangan akan diperlakukan sebagai hukum." 29

Berdasar dari uraian sebelumnya dapat dipahami bahwa sumber-sumber hukum dalam Islam ada empat, yakni Alquran, hadis, ra'yu, dan pendapat ulama. Keempat sumber hukum yang disebutkan ini, juga merupakan sumber nilai dan norma yang oleh Shaifuddin Anshari mengklasifikasinya atas dua, yakni sumber pokok dan sumber tambahan. Sumber pokok, adalah Alquran dan hadis, dan sumber

${ }^{29}$ H. Abd. Muin Salim, "Konsepsi Hukum dalam Alquran," Makalah Seminar Tanggal 15 Juni 1994 (Ujungpandang: Fakultas Syariah IAIN Alauddin, 1994), 2. 
tambahan adalah ijtihad, yakni ra'yu dan pendapat ulama, atau selainnya, misalnya qiyas, istihsan, istislah, saddu al-syara'i.

Sumber pokok hukum Islam, yakni Alquran dan hadis, tidak hanya berisi tuntunan ritual belaka, tetapi juga berisi ajaran-ajaran dasar berupa nilai-nilai yang sangat diperlukan dalam penyusunan tertib masyarakat di samping aturan-aturan yang telah ditetapkan Allah dan Rasul-Nya untuk diamalkan. Namun suatu saat, Alquran dan hadis tersebut memerlukan interpretasi lebih lanjut, dan dengan upaya interpretasi itulah melibatkan al-ra'yu. Dalam kenyataannya, interpretasi hukum yang dihasilkan oleh al-ra'yu ulama seringkali ditemukan perbedaan pendapat. Namun perbedaan itu bukanlah merupakan aib asalkan saja produk hukum yang dihasilkannya itu tetap mengacu pada sumber pokoknya, yaitu Alquran dan hadis.

Persoalan lain yang dihadapi adalah sejauh mana kewenangan para ulama masa kini membuat hukum. Hal itu amat penting karena dalam sistem fikih Islam sebagaimana yang telah disebutkan sumber hukum yang diakui selain Alquran dan Sunnah adalah ijma' dan qiyas. Bahkan juga beberapa sumber lainnya yang diperselisihi seperti istihsan dan maslahat mursalah. Mungkin ada yang berpendapat bahwa apa yang disebut sebagai sumber hukum ini adalah beberapa metode pembuatan.

Hirokoshi mengemukakan salah satu fungsi ulama adalah ahli dan menguasai hukum. UIama sebagai pengajar dan pendidik masyarakat Islam yang bertugas menjaga dan menafsirkan hukum-hukum dalam Islam. Alquran dan hadis sebagai pedoman umat Islam sebagian besar mengatur hukum-hukum. Ketika masyarakat mengalami kesulitan dalam memahami hukum-hukum dalam Alquran dan hadis tersebut, maka fungsi ulama sebagai penafsir terhadap aturan hukum yang belum dipahami oleh umat Islam. ${ }^{30}$

Menurut Hamka Haq bahwa ulama untuk mengetahui hukum dalam menghadapi dua kemungkinan dalam penggunaan nalarnya, yaitu: Pertama, mungkin mereka dapat langsung mengetahui hukum tersebut setelah menelaah dan mengkaji sejumlah nash-nash yang dapat memberi pengertian induktif tentang

\footnotetext{
${ }^{30}$ Hiroko Horikoshi, Kiyai dan Perubahan Sosial (Jakarta: P3M, 1976), 140.
} 
hukum yang digali; iniilah disebut fikih tekstual (al-fiqh al-manshusah); Kedua, ulama dapat mengetahui hukum tentang suatu perbuatan setelah menggunakan lebih banyak nalar, hal ini dikarenakan obyek hukum yang dimaksudkan tidak disebut secara tegas oleh nash-nash syariat; inilah disebut fikih kontekstual berdasarkan ijtihad (al-fiqh al-ijtihadi). ${ }^{31}$

Berkenaan dengan itu, dapat dirumuskan bahwa para ulama memiliki berbagai kelebihan dan keutamaan serta ciri-ciri khusus yang tidak dimiliki oleh makhluk selainnya. ${ }^{32}$ Salah satu kelebihan dan keutamaan yang dimilikinya ialah diberikannya amanah untuk menetapkan hukum, dan kewenangannya ini hal ini mengacu pada kedudukan mereka sebagai pewaris nabi (warasat al-anbiya), yakni melanjutkan estapet risalah kenabian, termasuk membuat hukum setelah para NabiNabi dan Rasul-Rasul telah tiada.

Namun perlu dipertegas bahwa kewenangan hukum yang dibuat oleh ulama yang dimaksudkan adalah sesuatu yang memang tidak ditemukan secara jelas dalam Alquran dan hadis, misalnya; ulama fikih menetapkan hukum KB dibolehkan pelaksanaannya dengan pertimbangan seperti: faktor ekonomi, faktor kesehatan dan faktor pendidikan. Hal ini berarti dibolehkan bagi orang-orang yang tidak sanggup membiayai kehidupan anak; kesehatannya dapat terganggu dan pendidikan anak akan terbengkalai. Olehnya itu orang tuanya agar menjadi akseptor KB. Bahkan orang tua yang melakukanya akan mendapatkan dosa jikalau melahirkan anak yang tidak dapat dijaga dan dijamin masa depannya, kemudian akhirnya akan menjadi beban berat bagi masyarakat. ${ }^{33}$ Contoh lain yang kini diperdebatkan adalah hukum perayaan natal bersama. Dalam kasus ini, sebagian ulama di Indonesia berpandangan bahwa perayaan natal di Indonesia walaupun tujuannya untuk merayakan dan menghormati Nabi Isa as., namun natal tersebut tidak terpisahkan

\section{7.}

${ }^{31}$ Hamka Haq, Syariat Islam: Wacana dan Penerapannya (Makassar: Yayasan Ahkam, 2003),

${ }^{32}$ Muhammad bin Muhammad Abu Hamid Gazali, Mukhtasar Ihya' Ulum al-Din (Cet. I; Beirut: Dar al-Fikr, 1993 M./1414 H), 25.

${ }^{33}$ H. Mahjuddin, Masailul Fiqhiyah: Berbagai Kasus yang Dihadapi Hukum Islam Masa Kini (Cet. IV; Jakarta: Kalam Mulia, 2003), 61. 
dari ibadah umat Kristiani, sehingga dibuatlah ketentuan hukum melalui fatwa ulama bahwa natal bersama bagi umat Islam hukumnya adalah haram.

Peran ulama sebagai pembuat keputusan hukum tersebut menempatkan posisi ulama dalam lintasan sejarah sebagai tahkim, yaitu sebagai pencari solusi terhadap berbagai persoalan yang muncul dan dihadapi di tengah-tengah masyarakat. Misalnya di dalam Alquran dijumpai ayat yang menjadi landasan bagi pelaksanaan peran para ulama dalam mencari solusi hukum terhadap persoalan yang muncul dan dihadapi oleh masyarakat, yaitu:

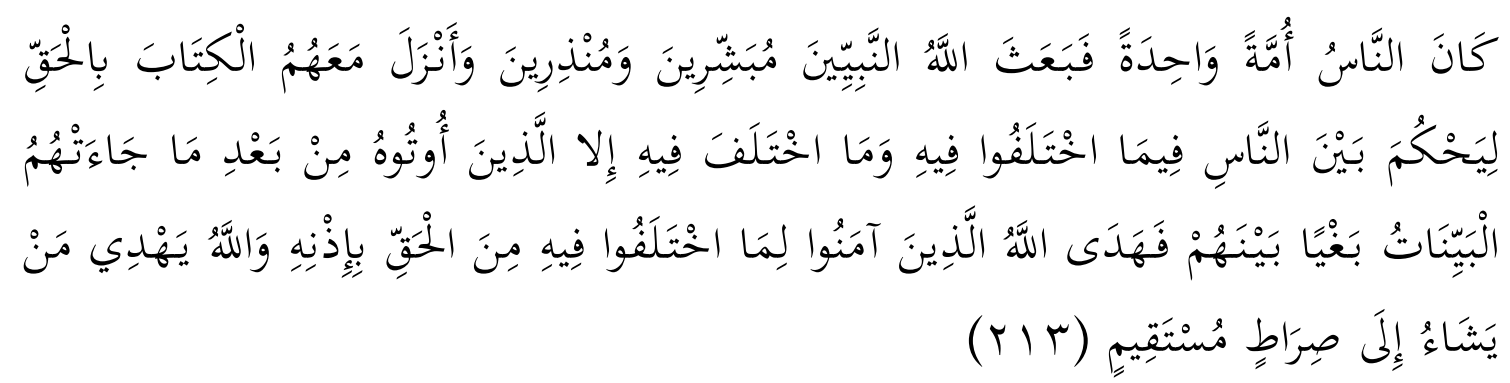

Terjemahnya:

Manusia itu (dahulunya) satu umat. Lalu Allah mengutus para nabi (untuk) menyampaikan kebar gembira dan peringatan. Dan diturunkan-Nya bersama mereka Kitab yang mengandung kebenaran, untuk memberi keputusan di antara manusia tentang perkara yang mereka perselisihkan. Dan yang berselisih hanyalah orang-orang yang telah diberi (Kitab), setelah bukti-bukti yang nyata sampai kepada mereka, karena kedengkian di antara mereka sendiri. Maka dengan kehendak-Nya, Allah memberi petunjuk kepada mereka yang beriman tentang kebenaran yang mereka perselisihkan, Allah memberi petunjuk kepada siapayang Dia kehendaki ke jalan yang lurus (QS al-Baqarah/2: 213). ${ }^{34}$

Ada beberapa ide pokok yang terkandung dalam QS al-Baqarah/2: 213 tersebut, yaitu: Pertama, bahwa Allah swt. menciptakan manusia pada mulanya sebagai umat yang satu (sebelum terjadinya tragedi pertikaian); Kedua, bahwa Allah mengutus para Nabi untuk membawa berita gembira dan memberi peringatan kepada umat manusia; Ketiga, bahwa Allah menyertakan al-Kitab kepada para Nabi sebagai acuan untuk memecahkan berbagai problema yang menjadi perselisihan yang terjadi di tengah masyarakat. Tiga ide pokok dalam QS al-Baqarah/2: 213

\footnotetext{
${ }^{34}$ Kementerian Agama RI., Ummul Mukminin: Al-Quran dan Terjemah untuk Wanita (Jakarta: Penerbit Wali, 2010), 33.
} 
pada dasarnya merupakan tugas Nabi Muhammad saw., namun di era kekinian adalah menjadi tugas ulama sebagai pewaris para Nabi.

Hanya saja, tetap harus diakui bahwa peran ulama suatu saat nanti dapat saja berubah, dan hal itu dilatarbelakangi adanya tipologi ulama yang bervariasi di masa kini. Sekurang-kurangnya terdapat lima tipologi masa kini ini, yaitu: ulama plus, ulama pulus, ulama dunia, ulama akhirat, dan ulama dunia dan akhirat.

Munawir Syadzali dalam karyanya Bunga Rampai Wawasan Islam Dewasa Ini, menjelaskan lima tipe ulama sebagai berikut: 1) Golongan ulama yang telah meninggal; 2) Golongan ulama yang ditinggal umatnya; 3) Golongan ulama yang meninggalkan umat; 4) Golongan ulama yang ketinggalan zaman; dan 5) Golongan ulama yang tetap tinggal bersama umat. Dalam menguraikan kelima tipologi ulama tersebut, Munawir Syadzali berpendapat bahwa golongan yang pertama dan terakhir sajalah yang memperoleh keberuntungan. ${ }^{35}$

Demikian pula Imam al-Gazali dalam Ihya Ulumuddin, menjelaskan dua tipe ulama, yaitu: ulama akhirat dan ulama dunia (ulama su'). Dengan rinci mengemukakan tipologi ulama dengan argumentasi absah. Selanjutnya ia mengemukakan tanda-tanda ulama akhirat sebagai berikut: (1) Tidak mencari kemegahan dunia dan menjadikan ilmunya untuk kepentingan dunia; (2) Perilakunya sejalan dengan ucapannya (akhlak al-mahmudah); (3) Mengajarkan ilmunya untuk kepentingan akhirat, mengutamakan ilmu yang dapat mendekatkan dirinya dengan Tuhan, serta menjauhi perdebatan yang sia-sia; (4) Mengejar kehidupan akhirat dengan mengamalkan ilmunya dan menunaikan berbagai ibadah; (5) Menjauhi godaan penguasa jahat; (6) Tidak tergesa-gesa mengeluarkan fatwa sebelum menemukan dalil; (7) Senang kepada ilmu yang dapat mendekatkan diri kepada Allah, cinta kepada musyahadah, muraqabah, dan optimis terhadap rahmatNya; (8) Berusaha semaksimal mungkin untuk mencapai haqq al-yakin; (9) Senantiasa khasyah kepada Allah, ta'zhim akan kebesarannya, hidup sederhana dan

\footnotetext{
${ }^{35}$ Munawir Syazdali, Bunga Rampai Wawasan Islam Dewasa Ini (Jakarta: UI Press, 1994), 3132.
} 
berakhlak mulia; (10) Menjauhi segala yang membatalkan ilmu dan kesucian hatinya; dan (11) Memiliki ilmu yang berpangkal dalam hati. ${ }^{36}$

Terlepas dari mengomentari tipologi ulama di atas di atas, baik yang dikemukakan oleh Munawir Syadzali maupun yang dikemukakan oleh al-Gazali, Alquran sesungguhnya telah memaparkan mengenai tipologi yang dimiliki oleh ulama sebagai pewaris kitab suci. Penunjukan ulama sebagai pewaris kitab Allah swt. sangat logis adanya, sebab jika ditunjuk sebagai pewaris hanya di kalangan para Nabi dan rasul untuk selanjutnya disampaikan kepada para umatnya, berarti prores transformasi wahyu telah berakhir dengan wafatnya para Nabi dan Rasul, namun pada kenyataannya upaya tersebut tidak pernah berhenti hingga sekarang. Dalam hal ini ulamalah yang menggantikan para Nabi dan Rasul dalam mengemban risalah tersebut untuk disampaikan kepada umat manusia.

\section{E. Penutup}

Pemahaman terhadap arti fuqaha atau ulama adalah mereka yang bertaqwa, berbudi luhur, menguasai berbagai bidang ilmu pengetahuan, serta mengimplementasikannya dalam masyarakat. Namun dalam konteks keindonesiaan terminologi ulama diidentikkan dengan fukaha. Bahkan dalam pengertian seharihari, ulama adalah fukaha dalam bidang ibadah saja. Dalam upaya menciptakan ulama masa depan, maka pembinaan generasi dalam bentuk pengkaderan ulama sangat dibutuhkan, dan hal ini dapat dilakukan melalui jalur pendidikan formal dan melalui jalur pelatihan secara terprogram. Dalam pengkaderan tersebut, harus diisi dengan materi-materi yang benar-benar dibutuhkan dalam melaksanakan tugas keulamaan masa depan.

Untuk upaya pengkaderan, baik pada masa Rasulullah saw. dan Khulafa' alRasyidun, masa pembentukan mazhab, maupun masa kini dan ke depan, memiliki tata cara (metode) yang berbeda. Pada masa Rasulullah saw. dan Khulafa' alRasyidun segala persoalan yang timbul dapat langsung ditanyakan kepada Rasul

\footnotetext{
${ }^{36}$ Muhammad bin Muhammad Abu Hamid Gazali, Ihya' Ulum al-Din, Juz 1 (Singapura: Sulaiman Mar'a, 1992), 60-68.
} 
Studi Historis Perkembangan Kaderisasi Ulama dalam

Menghasilkan Fukaha

saw. atau sahabatnya; Pada masa pembentukan mazhab, para ulama mempergunakan sumber-sumber pokok dalam pengambilan keputusan hukum (fiqh) dengan skala prioritas urutan sumber hukum tersebut; Sedangkan pada masa kini dan sekarang, upaya pengkaderan ulama melalui jalur pendidikan formal maupun pelatihan.

Sebagai fukaha, maka ulama dalam posisinya sebagai pewaris Nabi saw, harus memfungsikan dirinya sebagai tahkim, yaitu sebagai pencari solusi terhadap berbagai persoalan hukum yang muncul di tengah-tengah masyarakat. Jadi dalam Islam, sumber-sumber hukum ada empat, yakni Alquran, hadis, ra'yu, dan pendapat ulama. Sumber pertama dan kedua, adalah sumber pokok dan selebihnya adalah sumber tambahan. Karena demikian halnya, maka batas kewenangan ulama dalam membuat hukum adalah sesuatu yang memang tidak ditemukan secara jelas dalam Alquran dan hadis.

\section{Daftar Pustaka}

Abdulloh. "Sistem Perencanaan Pendidikan Kader Ulama (PKU) Sarjana Strata Satu (S1) pada Komisi Pendidikan Majelis Ulama Indonesia (MUI) Pusat," Skripsi. Jakarta: UIN Syarif Hidayatullah, 2012.

Assiroji, Dwi Budiman. "Konsep Kaderisasi Ulama di Indonesia," Edukasi Islami: Jurnal Pendidikan Islam, Vol. 09/No 01 Februari 2020.

Azra, Azyumardi. Esei-Esei Intelektual Muslim dan Pendidikan Islam. Jakarta: Logos Wacana Ilmu, 1998.

. Pendidikan Islam: Tradisi Modernisasi Menuju Milenium Baru. Jakarta: Logos Wacana Ilmu, 2002.

. Jaringan Ulama: Timur Tengah dan Kepulauan Nusantara Abad XVII dan $X$ VIII. Cet. II; Jakarta: Prenada Media, 2005.

Bell, Daniel. The Coming of Post Industrial Society dalam Abuddin Nata, Kapita Selekta Pendidikan Islam: Isu-Isu Kontemporer tentang Pendidikan Islam, Ed. 1. Cet. 2; Jakarta: RajaGrafindo Persada, 2013.

Al-Bukhariy, Abi Abdillah Muhammad bin Ismail bin Ibrahim bin al-Mugirah bin Bardzbah al-Ja'afiy, Shahih al-Bukhariy, al-Kitab al-Adzan, al-Bab al-Adzan 
Lilmusafir idza Kanu Jama 'atan, No. Hadis: 595, dalam Mausu’ah al-Hadits alSyarif ver. 2 [CD ROM]. Jami“ al-Huquq Mahfudzah li Syirkah al-Baramij alIslamiyah al-Dauliyah, 1991-1997.

Daulay, Haidar Putra. Dinamika Pendidikan Islam di Asia Tenggara. Cet. I; Jakarta: PT Rineka Cipta, 2009.

Dhofier, Zamakhsyari. Tradisi Pesantren: Studi tentang Pandangan Hidup Kyai. Jakarta: LP3ES, 1982.

Direktorat Pendidikan Tinggi Islam, Petunjuk Teknis Bantuan Program Peningkatan Mutu Penelitian Tahun 2015. Jakarta: Kementerian Agama RI, 2015.

Gazali, Muhammad bin Muhammad Abu Hamid. Ihya' Ulum al-Din, Juz 1. Singapura: Sulaiman Mar'a, 1992. Mukhtasar Ihya’ Ulum al-Din. Cet. I; Beirut: Dar al-Fikr, 1993 M./1414 H.

Haq, Hamka. Syariat Islam: Wacana dan Penerapannya (Makassar: Yayasan Ahkam, 2003.

Horikoshi, Hiroko. Kiyai dan Perubahan Sosial. Jakarta: P3M, 1976.

Isnanto, Muh. "Gagasan dan Pemikiran Muhammadiyah tentang Kaderisasi Ulama (Studi Kasus tentang Ulama di Muhammadiyah)," Aplikasia: Jurnal Aplikasi Ilmu-ilmu Agama, Vol. 17, No. 2, 2017

Kementerian Agama RI. Ummul Mukminin: Al-Quran dan Terjemah untuk Wanita. Jakarta: Penerbit Wali, 2010.

Mahjuddin, H. Masailul Fiqhiyah: Berbagai Kasus yang Dihadapi Hukum Islam Masa Kini. Cet. IV; Jakarta: Kalam Mulia, 2003.

MUI Sulawesi Selatan. Brosur Pendidikan Kader Ulama. Makassar, 2000.

Murdan, "Pondok Pesantren dalam Lintasan Sejarah" dalam Ittihad Jurnal Ilmi: Keagamaan, Pendidikan dan Kemasyarakatan, Vol. 2 No.1 April 2004.

Rahardjo, Dawam. Ensiklopedi al-Qur'an “Ulama”, Ulumul Qur'an, No. 5, Volume VI, Tahun 1996.

Rahmat, Jalaluddin. Dahulukan Akhlak di Atas Fiqih. Cet. I; Jakarta: Mizan, . 2007.

Rama, H. Bahaking. Sejarah Pendidikan Islam. Cet. I; Jakarta: PT. Pradotama Wiranegara Gemilang, 2002.

Salim, H. Abd. Muin. "Konsepsi Hukum dalam Alquran,” Makalah Seminar Tanggal 15 Juni 1994. Ujungpandang: Fakultas Syariah IAIN Alauddin, 1994. 
Studi Historis Perkembangan Kaderisasi Ulama dalam

Menghasilkan Fukaha

Ash-Shiddieqy, T. M. Hasbi. Pengantar Ilmu Fiqh. Cet. VIII; Jakarta: Bulan Bintang, 1993.

Syazdali, Munawir. Bunga Rampai Wawasan Islam Dewasa Ini. Jakarta: UI Press, 1994.

Voll, J. O. "Scholarly Interrelations between South Asia and Middle East in the $18^{\text {th }}$ Century," Proccedings of The South Asia Seminar, University of Pennyslvania), Vol. 3, 1988.

http://pbsb.ditpdpontren.kemenag.go.id/pdpp/

https://eduaksi.com/pendidikan-4-0-apa/

https://id.wikipedia.org/wiki/Daftar_perguruan_tinggi_Islam_negeri_di_Indonesia 